\title{
JUURNAL.RU
}

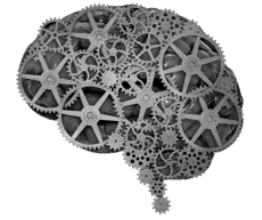

COMPANY GROUP "INTELLEKT"

\author{
Нестерова Г.А. \\ Образовательной школа № 38 \\ Рязань, Россия
}

doi: 10.18411/lj2016-9-1-11

idsp 000001: lj2016-18-1-11

\section{Диалектная лексика, характеризующая наименования одежды, обуви и головных уборов, в романе Бориса Можаева «Мужики и бабы»}

Диалектное и этнографическое своеобразие современной Рязанской области объясняется историческими причинами. Благодаря географическому положению и историческому прошлому Рязанский край занимает особое место: по нему проходит граница леса и степи, здесь завязывался так называемый славянский узел. В месте сосредоточения племенных групп, как известно, хорошо сохраняются реликтовые черты быта.

Предлагаемая статья знакомит читателей с диалектной лексикой Рязанского края в произведении Б.А. Можаева «Мужики и бабы». Традиционный народный костюм является одним из устойчивых элементов материальной культуры народа, ведущим признаком этнических особенностей, отражает связи и взаимоотношения русского народа с соседними этносами, а также испытывает изменения под влиянием моды. Именно поэтому я обратилась к наименованиям одежды, обуви и головных уборов, так как это представляет большой, сложный пласт лексической системы русских народных говоров.

Обращение к заявленной тематической группе тем более актуально, что в настоящее время подавляющее большинство наименований народного костюма сохраняется исключительно в речи и памяти представителей старшего поколения в результате утраты традиционных предметов одежды из обихода.

Ключевые слова: говор, диалект, диалектнаялексика, региональноеслово, архаическая лексика, понева, понька, зипун, онучи, свитка, капор. 
Изучая русские говоры, исследователи обращаются к живым говорам, к научным и документальным материалам. Одним из интересных источников является художественная литература. В творениях писателей находят отражение живая народная речь и народная культура. Академик И.И. Срезневский подчеркивал, что народный язык должен быть главным предметом внимания филологов, так как знание русских говоров позволит избежать потерь в изучении языка и культуры. Ученый указывал на взаимосвязь изучения быта, культуры народа и языка: «Чтобы понять словесность народа, надобно изучить его слово, его язык; чтобы понять народность в словесности, слове, надобно изучить народ, его характер, нравы, быт, умственные понятия...»

Одним из инструментов описания культуры народа являются говоры русского языка. Диалектная лексика в нем многочисленна и разнообразна, часть из нее вошла в русский литературный язык и обогатила его. Вопрос об использовании диалектных слов в литературных произведениях на протяжении долгих лет вызывал интерес многих ученых и писателей. Одни высказывались «за», другие «против» употребления диалектизмов в художественных произведениях. Одни всячески приветствовали живые, народные слова, расцвечивающие ткань литературного произведения, другие упрекали писателей в злоупотреблении диалектными словами. Таким образом, существовали полярные точки зрения на вопрос о допустимости использования диалектизмов в литературных произведениях.

Борис Андреевич Можаев, которого справедливо считают одним из классиков современной литературы, в своих произведениях широко использовал диалектную лексику. Ее можно разделить на несколько тематических групп: одежда, еда, напитки, растения, животные, человек, названия хозяйственных и жилых построек, сельскохозяйственные орудия труда, предметы домашнего обихода. Автор никогда не терял связи с родными пителинскими местами. Воспоминания детства, рязанские (пителинские) говоры, которые он слышал, все это осталось в его памяти, это наследие родного Рязанского края он запечатлел в созданных им произведениях.

При описании своих персонажей особенно большое внимание писатель уделяет одежде, головным уборам и обуви. Через слово и описание реалий Борис Андреевич Можаев передает колорит родных мест. В одежде, как и в слове, 
заключена информация о принадлежности человека определенной местности.

В романе «Мужики и бабы», посвященном коллективизации на территории Рязанского края, встречаемся с подробным описанием крестьянок, одетых в рубахи, юбки поньки и белые запоны. Мещерские села и их жители, называемые в романе «залесными глухарями», дольше всех, пожалуй, сохраняли приверженность старому костюму, традициям, обычаям. В произведении часто встречается упоминание домотканой юбки, которую носили замужние женщины:«Вззле мельницы обочь дороги стали попадаться пантюхинские бабы; они шли в полосатых поневах и в ярких цветастых платках; «На святках этой зимой в толпе ряженых выделялась дюжая баба в цветной поньке, в нагольной шубе и при маске» (с. 55).

Понька - элемент русского народного костюма. Женская шерстяная юбка замужних женщин из нескольких кусков ткани с богато украшенным подолом ( т. 3, с. 289)( ряз.вор.тмб ).

Три типа поневы, широко распространенные в Рязанском крае еще в конце XIX - начале XX в., связывают с тремя потоками славянской колонизации данного региона. В тексте Б. Можаева упоминается понева, которую этнографы называют кривичской, поскольку ареал ее бытования совпадает с границами территории, которую колонизовало славянское племя кривичей. Это тяжелая двухцветная красная и синяя понева восточной части области, сохранившая двуцветность как в архаических типах (синятка,полосатка ), так и в более поздних (синяя клетушка, красная дранишница).Даже теперь на свадьбе в Касимовском и Кадомском районе можно увидеть двуцветныекраснятку и синятку.

Запон- передник, фартук. (Костром., Брян., Куйбыш., Пенз., Нижегор., Яросл.) Это слово отмечено всеми диалектными словарями русского языка.

Передник или фартук в Рязанском крае носили женщины и девушки поверх рубахи, поневы, юбки, сарафана как в праздничные, так и в будничные дни. Лексема запон является наиболее употребительной в рязанских говорах, обозначая любую разновидность фартука.

Рушник - полотенце, подаваемое гостям за обеденным столом вместо салфеток (Волог, Арх, Пск, Твер, Моск, Калуж, Смол, Тамб, Вят.). В других словарях рушник - это свадебный головной убор.«Вышли молодайки в длинных поневах да с белой перевязью широких рушников». 
В романе «Мужики и бабы» несколько раз встречается слово ватола: «- Так вот тебе ватола и зипун. Ложись и укрывайся»; «-Ватола, она, робятки, влагу гонит,- говорил Селькин, принимая все это добро. На ней не больно уснешь. Вот зипунишко - это хорошо. Эта подстилка сухая... »; «Но теперь он Буланца пристегнул; во-первых, ватолу отец крепко приторочил на Белобокую, чтобы отвязать-повозиться надо, а во-вторых, не лошадьми были заняты мысли его».

Ватола- самая толстая и грубая крестьянская ткань; основа из самой толстой пряжи, уток из легко скрученных охлопков, толщиною с гусиное перо (вор.ряз. тмб.).

Большое внимание Борис Можаев уделяет верхней сезонной мужской и женской одежде.

Зипун - русский кафтан без стоячего ворота, изготовленный из грубого самодельного сукна: «Под зипун надел, онучи натянул, картуз новый на нем»; «Ларион быстро снял валенки, натянул сапоги, прихватил зипун, и они вышли»; «Маклак скинул лапти, быстро переобулся в штиблеты и зипуном их еще почистил, рубашку расшитую расправил, все складочки за спину разогнал».

Лексема зипун была общеупотребительной в Рязанском крае еще в XVIXVII вв. при обозначении одежды, мужской и женской, господской и крестьянской. Крестьянский зипун - одежда типа крестьянского кафтана, которую шили из сермяжного сукна.

В одном из фрагментов романа читаем: «Шуба на козьем меху, крытая драпкастором, бекеша из кенгуру - пальто с бобровым воротником». Здесь упоминается зимняя одежда, которую шили из овчин. Наиболее распространенным видом этой одежды являлась шуба. Она могла быть прямого покроя с клиньями или с облегающим лифом и сборами сзади и носила наименование бекеша.

Драп - кастор -сукно разного вида и достоинств, из бобрового (речного бобра) пуху.

Бекеша - накидка, верхняя одежда.

Свитка - широкая, долгая запашная одежда, без перехвата.

Слово свитка означает мужской пиджак (брянские говоры), рубаху, сорочку (орловские, калужские), легкую женскую одежду вроде сарафана, а также 
праздничную одежду (вологодские), одежду наподобие жилета (ярославские) и старую рваную одежду (псковские и калининские говоры).

В романе Борис Можаева читаем: «Дак вот, когда Гредная их стирает, он спит, завернувшись в свиту»; «У него кроме свиты ничего из одежды нет»; «Когда выехали на улицу, Иван накинул свитку на бушлат и поднял высокий стеганый воротник».Примечательно, что в рязанских памятниках XVII в.свита, свитка одежда духовного сословия (дьяконов, архиепископов), которая шилась из сукна и холстины.

На праздники люди старались одеть все самое нарядное и красивое. $\mathrm{He}$ только женщины, но и мужчины выделялись необычностью своих костюмов. Для изготовления использовали качественную ткань.

Коленкор - бумажное полотно, тонкая хлопчатая ткань.

Посконный холст, лучший, крестьянский рубашечный.

Рубаха с гайтанами - верхняя часть рубахи, шейное или нагрудное украшение.

Гайтан - синяя или красная тесьма, которой обшивают воротник, а иногда и рукава в мужских сорочках: «На мужиках суровые рубахи с расшитыми отложными воротниками, с жесткими стоячими гайтанами; бабы в тройном облачении: снизу рубаха полотняная, белая с красными ластвицами - широкими врезками подмышкой на пухлых вышитых рукавах; на рубаху надевается в ярких разноцветных полосах суконная юбка - понька, а поверх всего - белый запонурезанный сзади по талии сарафан с кумачовым обкладом по вороту, с черной вышивкой и множеством блестящих стеклянных пуговиц до самого подола. Да еще пояс плетеный, шириной три пальца с длинными яркими кистями, свисающими на правое бедро... А ноги у всех толстые, обутые по- зимнему в белые онучи да в лапти - семирники».

Названию обувиавтор также уделяет особое внимание.

Онучи - куски полотна, предназначавшиеся для обертывания ног; портянки, подвертки.«- Онучи забыл снаружи». «Я поглядывал на мокрые онучи гостя, на разбухшие и врезавшиеся в них оборы, на головашки лаптей ».«Сперва пришел дед Агафон; в посконной рубахе, в синих молескиновых штанах, заправленных под онучи, худой и малорослый, как подросток, он стукнул палкой в высокое окно Бородиных». 
Семирники- это лапти в семь лык, с мотивирующей основой семь.

Оборы - завязки, продетые в боковые ушки лаптей, ими привязывали лапти к ноге.«- Иван! Ты вылезешь или нет? Ай в оборах запутался?». «-Оборы от лаптей продаешь? - с усмешкой спросил Прокоп».

Шевровые (ботинки)-сорт мягкой хромовой козьей кожи: «- А ты скинь лапти-то, - сказал Чувал. К селу подойдем - в оврагах в тине вымажешь ноги. Пойдешь, как вшавровых ботинках». «На Чувале был черный отцовский картуз с лакированным козырьком да шевровые ботинки».

Не только в лексике одежды и обуви ярко проявляется национальное своеобразие, но и головных уборов. По данным рязанских говоров, основная номинанта для головных уборов женщин среднерусской деревни первой трети XX в. - платок. По представлениям современныхдиалектоносителей, именно платок является национальным головным убором русской женщины - жительницы среднерусской деревни. Уже в началеХХ в. платок становится характерным, почти единственным головным убором женщин.

Плат - платок: «В годах хозяйка, плат по самые брови повязан и лицом темна да нелюдима».

Девушки из обеспеченных семей могли позволить себе носить капор.

Капор- женская стеганая шапка на всю голову с завязками ( т.2,с. 86).

«Царица в санях что-то кричала, размахивая сорванным с головы розовым капором» (с. 14).

Камилавка- шапочка священника: «Так, бывало, и ходит по приходу: где нарукавники позабудет, где камилавку потеряет».

Итак, мы видим, что на территории только одной области зафиксировано довольно большое количество диалектных слов, представляющих собой общие названия одежды, обуви и головных уборов, которые классифицируются по ряду признаков. Изучая региональные слова этой тематической группы, мы погружаемся в самобытный мир прежней, уходящей или уже ушедшей деревни с ее своеобразием жизни - кропотливой, трудной работой, поэтичностью сельских вечеров, многоцветием праздников, знакомимся с колоритом рязанской местности. Это важный источник для изучения и описания народного языка и народной культуры. 


\section{Литература:}

1. Даль В.И. Толковый словарь живого великорусского языка. 4 т. - М.: Русский язык. 1981.

2. Срезневский И.И. История славяно-русской филологии: тенденции в науке, образовании и культуре. - Рязань, 2007. РГПИ.

3. Можаев Б.А. Мужики и бабы: роман. - М., 1998. Современник.

4. Осипова Е.П. «Язык рязанского костюма». Наименования элементов народной одежды в рязанских говорах, Рязань, 2004.

5. Словарь русских народных говоров под ред. Ф.П. Филина. М., Л. 1965. Институт русского языка АН СССР. Наука.

6. Орлова О.С. Диалектная лексика Рязанской области (учебное пособие) Рязань, 1981.

7. Лексический атлас русских народных говоров. Материалы и исследования 1998 Российская Академия наук Институт лингвистических исследований // Е.П. Осипова «Этнологическая база диалектных наименований одежды Рязанского края». Санкт-Петербург, 2001. 